\title{
REKONSTRUKSI NALAR PERADABAN ISLAM
}

\author{
Muh. Rusli \\ Institut Agama Islam Negeri (IAIN) Sultan Amai Gorontalo, Jl. Glatik No. \\ 1 Gorontalo.Tlp.085255460324. e-mail: muhammadruslii@yahoo.com
}

\begin{abstract}
Islam has enriched the glorious time in its early civilization period. However, it undergoes a set back later due to the wrong understanding of muslims to their religion. Therefore, it is necessary to reconstruct the logic of Islamic civilization to regain the gloriousness. Among those required efforts are such as to create a new spirit toward a new civilization, the will to adopt new knowledges without problematizing its sources, reconstructing the meaning of "God's free will", on being "tolerant ummah" and any efforts to strentheng the ummah.

Islam sejak awal telah mencapai puncak peradaban. Namun, peradaban Islam mengalami kemunduran karena umat Islam terperangkap pada pemahaman yang keliru. Untuk itu, perlu upaya rekonstruksi nalar peradaban Islam untuk mengembalikan kejayaan tersebut. Upaya yang dapat dilakukan antara lain membangun spirit baru menuju peradaban baru, kesediaan untuk mengadopsi ilmu pengetahuan tanpa mempermasalahkan sumbernya, begitu pula rekonstruksi makna "kehendak mutlak Tuhan", memposisikan diri sebagai "umat penengah", dan upaya pemberdayaan umat dari segala aspek.
\end{abstract}

Key words: reconstruction, Islamic civilization, ummah, science

\section{Pendahuluan}

Peradaban atau civilization adalah istilah yang biasa dipakai untuk menyebut bagian dan unsur dari kebudayaan yang halus, maju, dan indah. Misalnya, ilmu pengetahuan, kesenian, adat sopan santun pergaulan, kepandaian menulis, organisasi kenegaraan, dan sebagainya. Istilah "peradaban" sering juga dipakai untuk menyebut suatu kebudayaan yang mempunyai sistem teknologi, ilmu pengetahuan, seni bangunan, seni rupa, dan sistem kenegaraan dari masyarakat 
kota yang maju dan komplek (Koentjaraningrat, 2009: 146).

Peradaban suatu bangsa atau umat senantiasa mengalami pasang surut sesuai dengan perkembangan zaman, ada masa pertumbuhan, perkembangan/ kejayaan, dan ada pula masa kemunduran. Hal inilah yang dialami oleh peradaban Islam, sebab jika bercermin pada masa lalu, Islam telah menorehkan tinta emasnya pada sejarah peradaban dunia bahkan dianggap menjadi embrio lahirnya Renaisance di Eropa Barat dua-tiga abad sesudahnya. Sebagai gambaran kemajuan yang pernah dicapai oleh Islam, dan tidak bermaksud menafikan kemajuan yang dicapai oleh Umayyah di Spanyol - ujung belahan Barat Eropa, atau dinasti Fatimiyah di Mesir, perkembangan ilmu pengetahuan pada masa dinasti Abbasiyah dirasa cukup memberikan bukti betapa peradaban Islam pernah jaya dan menjadi pengendali ilmu pengetahuan.

Timur Tengah, dalam dunia Islam terkenal sekali perkembangan ilmu dan pengetahuan pada zaman khalifah Mansyur, Harun al Rasyid, dan al Makmun. Di zaman Khalifah Mansyur amat berkembang ilmu bahasa dan kesusastraan. Ketika itu hidup ahli-ahli yang meletakkan dasar filologi Arab, Sibawaih keturunan Persi, Khalil di Basrah dan al Kisa'i di Kufah. Terjemahan banyak dilakukan dari bahasa-bahasa India dan Parsi dan melingkupi karangan tentang astronomi dan matematika. Dalam waktu itu juga hidup Ibnuu al Muqaffa, seorang ahli besar tentang bahasa-bahasa Arab dan Parsi. Dialah yang menerjemahkan Kalilah wa Dimnah yang membuka jalan untuk berkembangnya aliran romantik bahasa Arab yang memuncak dalam Cerita Seribu Satu Malam. Ia jugalah yang menerjemahkan buku Sah Namah yang bermuatkan cerita rajaraja dan pahlawan-pahlawan Iran. Buku ini yang menjadi dasar epik Firdausi yang terkenal. Ibnuu al Muqaffa juga mengemukakan logika Aristoteles dan dengan demikian memberi alat untuk perkembangan pemikiran Islam (Alisjahbana, 2001: 4).

Di bawah pemerintahan Mansyur aliran rasionalisme Islam yang terkenal sebagai aliran Mu'tazilah mendapat kesempatan berkembang. Keliberalan Mansyur kelihatan pada minatnya pada kitab-kitab suci agama-agama yang lain. Ketika itu juga sarjana Islam mulai menyusun Hadits dan hukum. Abu Hanifah menyelesaikan sistem hukumnya masih di bawah Mansyur. Maliki dan Safi'i menyelesaikan sistem hukumnya di bawah Harun al Rasyid, sedangkan Hambali di bawah Makmun. Waktu Harun al Rasyid menerima kerajaan - Abbasiyah, buku dalam bahasa Arab sudah boleh dikatakan banyak dan ilmu-ilmu pengetahuan Islam telah jauh berkembang. Terkenal sekali Baitul Hikmah yang didirikannya untuk mengumpulkan dan menerjemahkan 
buku-buku yang banyak jumlahnya. Di bawah al Makmun yang menyokong dengan sungguh-sungguh aliran Mu'tazilah, Baitul Hikmah itu mencapai kejayaannya yang tertinggi sebagai pusat penerjemahan dari bahasa Yunani, sehingga terjadilah pertemuan antara ilmu pengetahuan India, Parsi, dan Yunani (Alisjahbana, 2001: 5).

Pada perpustakaan yang kaya akan buku itu dan pada sebuah observatorium yang dihubungkan kepada Baitul Hikmah itu, bekerja sarjana-sarjana dari berbagai bangsa dan kepercayaan, sebab al Makmun mendatangkan ke ibukotanya dari segala penjuru kerajaannya orang-orang yang paling menonjol di zamannya. Sementara itu pada zaman itu di Bagdad ada perpustakaan yang terbuka untuk setiap orang terdiri dari 14.000 jilid, di antaranya seratus kaligrafi al Quran oleh Ibnuu Muqla (Alisjahbana, 2001: 6).

Hal yang menarik dari dinasti Abbasiyah sehingga mengantarkan Peradaban Islam menjadi jaya adalah kecintaan para khalifah terhadap ilmu pengetahun tanpa mempermasalahkan dari mana sumbernya, bahkan mempekerjakaan para ilmuan dari berbagai agama-agama dalam sebuah wadah untuk menerjemahkan buku-buku dari berbagai sumber dan menyusun ilmuilmu baru. Sebuah potret pola pikir pemimpin yang terbuka terhadap ilmu pengetahuan. Seiring perjalanan waktu, peradaban Islam pun mengalami kemunduran, baik yang disebabkan faktor peperangan maupun karena faktor internal umat Islam itu sendiri. Kebangkitan Islam dari keterpurukan mulai nampak sejak periode modern (1800 M dan seterusnya). Jatuhnya Mesir ke tangan Barat menginsafkan dunia Islam akan kelemahannya dan menyadarkan umat Islam bahwa di Barat telah timbul peradaban baru yang lebih tinggi dan merupakan ancaman bagi Islam. Raja-raja dan pemuka-pemuka Islam mulai memikirkan bagaimana meningkatkan mutu dan kekuatan umat Islam kembali. Di periode Modern inilah timbul ide-ide pembaharuan dalam Islam (Nasution, tt: 13).

Sejak tahun $1800 \mathrm{M}$ dan seterusnya, ide-ide pembaharuan dalam Islam telah memberikan dampak positif bagi peradaban Islam, namun sampai hari ini dunia Islam masih belum mampu merebut kembali kendali ilmu pengetahuan yang merupakan kunci utama peradaban. Hal tersebut menjadi landasan penulisan artikel ini, mungkinkah umat Islam mampu merebut kembali kendali ilmu pengetahuan? Kendala-kendala apa yang dihadapi oleh umat Islam selama ini? Solusi apa yang terbaik bagi perkembangan peradaban Islam? 


\section{Problematika Peradaban Islam}

Setiap umat mengalami pasang surut dalam hal peradaban, tidak terkecuali umat Islam. Berdasarkan hal tersebut, problem yang dihadapi oleh umat Islam sampai hari ini di antaranya; 1) Belum maksimalnya pemanfaatan potensi yang dimiliki oleh umat Islam sehingga umat Islam belum mampu keluar dari problem yang melingkupinya; 2) Masih adanya keenggangan untuk mengadopsi ilmu pengetahuan yang lahir dari rahim negara Barat (non-Islam). Hal ini tentu berbeda dengan apa yang dilakukan oleh khalifah al Makmun begitupula Eropa Barat ketika menimba ilmu pada Timur Islam. Problemproblem yang menyebabkan keterbelakangan umat Islam masa kini antara lain (Mahmud, 1998: 72):

1. Keterbelakangan di bidang sains dan teknologi - yang menjadi instrumen mekanis bagi laju perkembangan modernisasi. Keterbelakangan umat Islam di bidang sains dan teknologi mempunyai hubungan kausalitas siklus dengan keterbelakangan ekonomi, kurangnya penghargaan terhadap waktu, kurangnya efisiensi dan efektivitas, sistem kerja yang tidak produktif dan tipisnya disiplin kerja.

2. Pemahaman Islam yang parsial, tidak integral sehingga Islam masih ditempatkan pada fungsi pengembangan spiritual dan orientasi ukhrawi semata. Dengan demikian, Islam tidak inheren dalam seluruh aktivitas manusia sehingga tidak menjadi orientasi etis dalam bekerja dan berproduksi. Etika kerja masih "etik instrumental", belum mengakar sampai "etika religious-transenden".

3. Tampilan keislaman masih apologik. Ajaran Islam ditempatkan sebagai “antitesis" terhadap pandangan non-Islam sehingga keislaman menjadi reaktif atau sebaliknya menjadi isolatif. Dengan demikian, keberagamaan tidak menjadi agen perubahan di tengah-tengah pandangan non-Islam.

4. Islam seringkali dibungkus dengan ideologi atau "mengideologikan Islam”, sehingga Islam ditampilkan dengan wajah "yang seram”, ekstrem, intoleran, dan eksklusif seperti yang dilakukan oleh kaum fundamentalis Islam di berbagai negara muslim (Mahmud, 1998: 72).

Meskipun terdapat berbagai problem yang menyebabkan keterbelakangan umat Islam, terdapat pula berbagai harapan bagi kemajuan Islam dan umatnya di masa depan, yakni:

1. Sampai kini Islam tetap dikaji oleh para intelektual muslim untuk mencari paradigma baru untuk menjadikan Islam sebagai agen perubahan sosial 
yang konstruktif.

2. Potensi demografis umat Islam yang berjumlah kurang lebih satu milyar dari lima milyar penduduk dunia dan potensi geografis negara-negara muslim sebagai penyuplai minyak dan gas bumi yang terbesar di dunia serta berbagai kekayaan alam lainnya.

3. Semakin meningkatnya pendidikan Islam di negara-negara muslim, cukup kondusif bagi pengembangan wawasan pengetahuan keislaman dan melahirkan cendekiawan/ulama yang mampu menyuarakan Islam serta membangun peradaban Islam (Mahmud, 1998: 73).

Dengan adanya potensi-potensi di atas, maka umat Islam memiliki harapan yang besar untuk kembali menancapkan peradabannya di dunia. Sebagai langkah awal, tentu saja dibutuhkan berbagai macam upaya serius oleh seluruh kompenen umat untuk mencari solusi terbaik dalam memecahkan setiap persoalan yang dihadapi oleh umat Islam.

\section{Alternatif Solusi Peradaban Islam}

Menyikapi problem tersebut, diperlukan upaya serius umat Islam untuk keluar dari problem yang melingkupinya. Untuk itu, beberapa hal yang dapat ditempuh sebagai berikut:

\section{Membangun Spirit Baru Menuju Peradaban Baru}

Salah satu aspek penting yang menunjang lahirnya peradaban Islam atau kembalinya kejayaan Islam, terletak pada kemampuan umatnya untuk merubah paradigma berpikir dan prilakunya dalam menyikapi ketertinggalan yang selama ini melanda dunia Islam. Membangun spirit baru untuk maju dan berperadaban yang dilandasi dengan spirit al Quran merupakan hal yang mutlak untuk dilakukan.

"Maka berpegang teguhlah kamu kepada agama yang telah diwahyukan kepadamu. Sesungguhnya kamu berada di atas jalan yang lurus" (QS az Zukhruf: 43).

Makna "berpegang teguhlah kamu kepada agama yang telah diwahyukan kepadamu" yakni Islam di mana al Quran diturunkan di dalamnya, dan dalam al Quran ayat yang pertama diturunkan adalah "iqra"” yang artinya bacalah. Dengan demikian umat Islam dituntut memaksimalkan seluruh potensi yang dimiliki untuk keluar dari setiap masalah yang dihadapinya.

Spirit al Quran sangat esensial karena al Quran memiliki arti penting bagi umat Islam yakni sebagai sumber dari persepsi mereka tentang pembangunan masa lalu, masa kini, dan masa yang akan datang (Basssam Tibi, 1999: 59). 
Selain berpegang teguh pada agama Islam, al Quran pun menganjurkan kepada umatnya untuk berupaya semaksimal mungkin untuk merubah nasIbnuya. Sebagaimana firman-Nya:

"...sesungguhnya allah tidak akan merubah keadaan suatu kaum, sehingga mereka merubah (keadaan mereka) sendiri...” (QS ar Ra'd: 11).

Berdasarkan ayat tersebut, Allah menyerahkan sepenuhnya kepada umat Islam apakah ia tetap pada keadaan semula atau bangkit menuju perubahan. Allah telah menganugerahkan potensi akal kepada manusia untuk berpikir dan bertindak. Penghargaan terhadap akal tidak harus dimaknai sebagai pendewaan kepadanya. Sampai hari ini, umat Islam terkesan masih terperangkap pada klaim dikotomi antara akal vs. wahyu, sehingga terkadang akal harus ditundukkan dan diselaraskan dengan maksud wahyu Allah sebagaimana yang ia fahami. Tentu saja hal ini muncul karena adanya kekhawatiran yang berlebihan dan tidak berdasar dalam menyikapi serbuan pemikiran dari segala lini, serta ketidak percayaan terhadap kemampuan akal dalam menalar firman Allah.

Kasus perang ideologi antara para filosof dengan al Ghazali dalam hal qadimnya alam, yang berlanjut pada pembelaan Ibnuu Rusyd terhadap filosof dan mencoba mendamaikan keduanya, merupakan bukti adanya ketegangan dalam hal memahami potensi akal manusia. Pasca al Ghazali, Islam terperangkap pada ideologi sami'na wa atha'na terhadap produk pemikiran yang mapan, tanpa upaya melakukan ijtihad baru. Maka dengan sendirinya pintu ijtihad pun tertutup.

Dengan demikian, membangun spirit baru menuju pradaban baru menghendaki ruang ijtihad dibuka kembali seluas-luasnya, sehingga akses bagi umat Islam untuk berkreasi dapat terwujud. Tidak terkecuali dalam hal rekonstruksi makna al Quran.

Menyikapi perkembangan ilmu pengetahuan yang sangat maju di seluruh belahan dunia, sangat potensial untuk melahirkan kembali peradaban baru dengan memanfaatkan kecanggihan ilmu pengetahuan yang ada. Sebagai analogi sederhana, jika pada masa lalu, ulama hadits harus bersusah payah, berbulan-bulan menelusuri pelosok-pelosok desa untuk mengumpulkan suatu hadits, kini dengan kecanggihan teknologi dan fasilitas yang ada cukup dengan mengklik komputer maka hadits yang dicari telah tersedia dengan mudahnya. Hal yang sama juga terjadi pada ilmu pengetahuan lainnya. Dengan demikian, sangat memungkinkan hasil ijtihad generasi sekarang melebihi hasil ijtihad ulama terdahulu. 


\section{Kesediaan untuk Mengadopsi Ilmu Pengetahuan tanpa Mempermasalahkan Sumbernya}

Tanpa bermaksud bernostalgia dengan masa lalu atau mengagumkan sejarah, kita patut bercermin pada sejarah awal Islam guna mendapatkan pelajaran yang berharga dari perjalanan sejarah tersebut.

Zaman Rasul Allah Nabi Muhammad SAW, kebudayaan Islam berkembang terus menerus sejalan dengan perkembangan pemikiran dan meluasnya kekuasaan politik dan daerah penganut Islam. Terbentuklah bermacam-macam struktur, ide, dan lembaga-lembaga dalam lapangan politik, lapangan ibadah, lapangan hukum, lapangan seni, lapangan ekonomi, lapangan sosial, dan bermacam-macam lapangan kebudayaan yang lain. Kebudayaan yang baru berkembang dengan berpokok kepada al Quran dan contoh-contoh perbuatan dan pikiran Nabi Muhammad SAW. dilanjutkan oleh Khalifah Rasidun dan Khalifah raja-raja. Agama dan kebudayaan Islam yang berbahasa Arab itu meluas dari pantai Atlantik sampai ke batas kerajaan Cina. Dan dalam perkembangannya, agama dan kebudayaan Islam itu, dengan berani ahli-ahli pikir dan pemimpin Islam mengambil kekayaan dan unsur-unsur dari berbagai kebudayaan tua yang telah beribu-ribu tahun usianya seperti kebudayaan Persia, Yunani, Romawi, India, malahan sampai-sampai kebudayaan Cina. Demikian pertama kali dapat dikatakan terjadinya penyatuan unsur-unsur segala kebudayaan besar yang terkenal dewasa itu dalam suatu wadah yang dinamakan Islam, dijiwai oleh pikiran dan etik al Quran dan memakai bahasa Arab (Alisjahbana, 2001: 1).

Perkembangan kebudayaan Islam yang berpusat pada al Quran itu ialah keberanian dan kedinamisannya menyerbu keluar dari keterbelakangan kebudayaan bangsa Arab, yang hidup terpencil di gurun-gurun pasir yang tandus, dan keluasan berpikir yang mendorong untuk mengambil apa yang dapat diambil daripada kebudayaan-kebudayaan tua yang telah beribu-ribu tahun usianya untuk menumbuhkan selanjutnya sebagai bagian dari dirinya sendiri. Dari kebudayaan Persia dan Bizantium antara lain diambil bermacammacam lembaga organisasi kenegaraan dan kemiliteran, bermacam-macam gaya upacara dan seni. India diambil antara lain matematika dan ilmu bintang. Yunani diambil antara lain filsafat dan ilmu. Sekalian yang diambil dari bermacam-macam kebudayaan yang berabad-abad dan beribu-ribu tahun usianya dipadu menjadi suatu kebudayaan Islam yang disana-sini menyesuaikan dirinya kepada kebudayaan-kebudayaan daerah, tetapi selalu masih nyata keislamannya. Dalam kebudayaan Islam itu unsur-unsur yang diperoleh dari 
kebudayaan-kebudayaan yang banyak itu tidak hanya ditiru dan diulang-ulang tetapi dikembangkan dan diberi bentuk keislaman padanya. Dengan demikian amat banyaklah yang tercapai dalam lima-enam abad perkembangan agama dan kebudayaan Islam tentang organisasi kenegaraan, ilmu pengetahuan, hukum, seni, pikiran-pikiran keagamaan, perdagangan dan sebagainya. Sejalan dengan itu, bermunculan ahli-ahli Islam dalam segala lapangan, dari hukum sampai kemiliteran, dari filsafat dan ilmu sampai ke seni, dan sebagainya (Alisjahbana, 2001: 2)

Jika bangsa Arab yang hidup dalam keterbatasan mampu bangkit dan menjamah seluruh khazanah keilmuan dari berbagai peradaban tertua, maka tidak ada alasan bagi generasi Islam untuk was-was terhadap westernisasi atau apapun namanya, yang selama ini menjadi alat pembenaran bagi dirinya untuk mengisolasi diri dari perkembangan ilmu pengetahuan dan dunia luar. Tentu saja mengadopsi seluruh khazanah pengetahuan yang tersedia tidak dimaknai sebagai plagiat atau tiruan, tetapi dikembangkan lebih jauh sehingga mampu mendorong lahirnya peradaban Islam yang baru.

Salah satu problem yang juga dialami oleh umat Islam dalam mengodopsi ilmu pengetahuan dari luar adalah ketidakmampuannya untuk keluar dari dogma ilmu Islam vs ilmu Barat/non Islam. Hal tersebut berdampak pada lahirnya isu islamisasi ilmu pengetahuan yang terkesan dipaksakan. Untuk itu, perlu upaya sadar untuk keluar dari dogma yang selama ini membelenggu lahirnya gagasan baru dalam ilmu pengetahuan.

\section{Rekonstruksi Makna "Kehendak Mutlak Tuhan"}

Kehendak mutlak Tuhan merupakan salah justifikasi bagi sebagain umat Islam dalam menyikapi tantangan zaman yang melingkupinya. Baginya, apa yang menimpa umat Islam hari ini adalah bentuk kehendak mutlak Tuhan yang harus diterima tanpa harus mengeluh. Bahkan tidak jarang ada yang berpendapat bahwa jika umat lain diberi kesenangan atau kemajuan duniawi hari ini, itu karena di akhirat nanti mereka tidak lagi berhak untuk mendapat kesenangan. Lain halnya dengan umat Islam yang menderita di dunia tetapi di akhirat akan mendapat kesenangan yang tiada taranya.

Paradigma menyerahkan nasib umat Islam sebagai kehendak mutlak Tuhan pada dasarnya memiliki pijakan dalam kajian teologi Islam yang dikenal dengan faham Jabariyah. Menurut paham ini, perbuatan manusia dicipakan Tuhan dalam diri manusia. Manusia tidak mempunyai kemauan dan daya untuk mewujudkan perbuatannya. Manusia tak ubahnya sebagai 
wayang yang tidak bergerak kalau tidak digerakkan dalangnya. Manusia tidak mempunyai kebebasan, semua perbuatannya telah ditentukan Tuhan semenjak azal (Nasution, 1984: 37). Namun Jabariyah bukanlah satu-satunya faham dalam Islam, munculnya paham Qadariyah, Mu'tazilah dan lainnya merupakan bentuk perlawanan atau ketidaksetujuan dari paham sebelumnya dalam menyikapi kehendak mutlak Tuhan.

Pada dasarnya, dalam hubungannya dengan manusia, Tuhan menghadapi materi, dan materi tersebut bersifat terbatas. Dalam menghadapi zat yang terbatas, kekuasaan dan kehendak Tuhan mesti pula terbatas. Dengan kata lain, sekiranya Tuhan dalam hubungannya dengan manusia tidak menghadapi materi yang bersifat terbatas, kekuasaan dan kehendak Tuhan tidak akan pula terbatas; kekuasaan dan kehendak-Nya akan bersifat mutlak. Hukum-hukum alam yang bersifat deterministis juga membuat kekuasaan dan kehendak Tuhan tidak mutlak lagi. Kalau kekuasaan dan kehendak mutlak Tuhan bersifat mutlak, alam tidak akan berjalan menurut peraturan tertentu, tetapi akan berjalan menurut kekuasaan dan kehendak mutlak Tuhan. Dalam peredaran alam akan terdapat kekacauan. Untuk menghindari kekacauan ini, Tuhan menentukan hukum-hukum alam yang bersifat deterministis dan yang dipatuhi alam dalam peredarannya (Nasution, 1973: 103).

Kekuasaan dan kehendak mutlak Tuhan juga dibatasi oleh pemikiran rasional. Tuhan umpamanya tidak dapat membuat kesalahan menjadi kebenaran, kejahatan menjadi kebaikan, keburukan menjadi kecantikan dan sebagainya. Tuhan selanjutnya tidak dapat berdusta dan tidak dapat menyalahi janji-janji-Nya. Berdusta dan menyalahi janji adalah sifat buruk yang tak dapat dilekatkan kepada diri Tuhan sebagai zat Yang Maha Suci. Selanjutnya Tuhan telah memberi kebebasan bagi manusia untuk menentukan apa yang dikehendakinya dan apa yang diperbuatnya. Kebebasan yang diberikan Tuhan kepada manusia ini dengan sendirinya membatasi kekuasaan dan kehendak Tuhan. Kalau Tuhan tidak membatasi kekuasaan dan kehendak-Nya dalam hal ini, manusia sebenarnya tidak mempunyai kebebasan. Ini bertentangan dengan kenyataan bahwa manusia tiap hari menentukan apa yang dikehendaki dan apa yang diperbuatnya. Tiap saat manusia dihadapkan dengan soal memilih dari beberapa alternatif yang dijumpainya dalam hidup sehari-hari (Nasution, 1973: 104).

Dapat dipahami bahwa kehendak mutlak Tuhan yang sifatnya tidak terbatas harus dicairkan atau disesuikan dengan sesuatu yang terbatas. Manusia, alam, pemikiran rasional adalah beberapa aspek yang mengharuskan Tuhan 
menyesuaikan kehendak-Nya agar dapat berhubungan dengan aspek tersebut. Jika tidak, maka tidak ada kehidupan di dunia ini. Hal yang sama juga dilakukan oleh Tuhan ketika menurunkan al Quran. Nalar al Quran disesuaian dengan nalar manusia sehingga memungkinkan sampainya maksud Tuhan kepada hamba-Nya. Hal ini mengindikasikan bahwa al Quran pun akan senantiasa berjalan dinamis sesuai dengan nalar para penafsirnya.

Paradigma menyerahkan nasib umat Islam sebagai kehendak Mutlak Tuhan telah mencederai semangat al Quran yang menekankan pentingnya manusia untuk tidak melupakan bagiannya di dunia (urusan dunianya) dan memaksimalkan usahanya untuk merubah keadaannya ke arah yang lebih baik.

Di samping itu, harus pula direnungkan bahwa pada dasarnya al Quran tidak pernah menjamin bahwa umat Islam yang selalu menang dalam pergolakan dunia, bahkan al Quran sendiri menyatakan bahwa hari-hari kemenangan itu dipergilirkan di antara manusia (baik muslim maupun non-muslim), seperti dinyatakan dalam firman-Nya.

"Iika kamu (pada perang Uhud) mendapat luka, maka sesungguhnya kaum (kafir) itupun (pada perang Badar) mendapat luka yang serupa. dan masa (kejayaan dan kehancuran) itu kami pergilirkan diantara manusia (agar mereka mendapat pelajaran); dan supaya Allah membedakan orang-orang yang beriman (dengan orangorang kafir) supaya sebagian kamu dijadikan-Nya (gugur sebagai) syuhada' dan Allah tidak menyukai orang-orang yang zalim"(QS al Imran: 140).

Ayat tersebut mengimplikasikan bahwa ada hukum historis yang diciptakan Allah yang berlaku di alam semesta ini, yaitu:

1. Bangsa yang menang atau unggul adalah bangsa yang pandai mengatur strategi, pandai menyusun langkah-langkah sistematis, memiliki keuletan, kemampuan dan ketabahan dalam menjalani hidupnya.

2. Bahwa agama hak yang dianut tidak menjadi jaminan untuk kemenangan dan keunggulan, kecuali jika nilai agama itu diterjemahkan dan direalisasikan dalam dimensi kehidupan. Kepercayaan agama bukan menjadi penyebab langsung bagi kemajuan dan keunggulan dalam peradaban, karena kepercayaan semata tidak dapat membuat sejarah, hanya tindakan-tindakan konkritlah yang dapat direkam oleh sejarah.

3. Ayat di atas juga mengimplikasikan bahwa umat Islam perlu menelaah sejarah masa lalu untuk antisipasi masa depan. Tujuannya agar diketahui bahwa manusia sendiri dan bukan Tuhan yang bertanggung jawab atas sejarah. Sejarah adalah akibat langsung dari tindakan manusia sendiri dalam sejarah. 
4. Agama dari Allah (Islam) mengandung energi yang "dahsyat" sebagai Nur dari Allah, harus dipadukan dengan energi yang ada pada manusia. Pemaduan antara kedua energi itu disebut oleh Muhammad Iqbal dengan "kerja sama manusia dan Tuhan untuk membangun suatu tata peradaban dunia” (Mahmud, 1998: 74).

Dengan demikian, peradaban Islam yang jaya, hanya akan menjadi mimpi belaka atau hanya menjadi istana dalam hayalan bilamana umat Islam hanya menunggu turunnya pertolongan Allah dengan jalan berdoa dan pasrah kepada-Nya. Peradaban Islam membutuhkan semangat yang membara, otak yang berilyan, tangan-tangan terampil, untuk mengolah setiap potensi yang ada dalam diri umat Islam sehingga mampu keluar dari keterpurukan.

\section{Memposisikan Diri sebagai "Umat Penengah"}

Di tengah-tengah percaturan pandangan dunia dan falsafah hidup yang aktual dewasa ini, al Quran menganjurkan agar umat Islam bertindak dan menempatkan diri sebagai "umat penengah" (ummatan wasathan), dan menjadi saksi atas perselisihan yang terjadi di antara manusia, bukan justru umat Islam menjadi aktor perselisihan itu. Falsafah hidup yang berkembang seperti: individualisme, sosialisme, materialisme, liberalisme, dan kapitalisme - yang walaupun semuanya adalah falsafah hidup bangsa Barat tetapi sudah merembes ke dalam masyarakat Timur dinetralisir oleh umat Islam. Hal tersebut terlihat dalam konsep ajaran Islam bahwa Islam adalah antitesis terhadap pandangan individualisme, karena dalam Islam juga diakui hak-hak individu. Individu tidak boleh larut sama sekali dalam sosial kolektivisme yang menghilangkan identitas individualitasnya. Sebaliknya, Islam tidak antitesis terhadap pandangan sosialisme, karena dalam Islam terdapat ajaran tentang nilai-nilai sosial dan berbagai persamaan dalam hak dan kewajiban umat Islam, tetapi sosialisme terlalu ekstrem karena tidak mengakui stratifikasi sosial.

Islam mengakui adanya stratifikasi sosial sebagai sunnatullah, tetapi ajaran Islam berusaha memperkecil jurang strata sosial atas dan strata sosial bawah. Islam pun menghargai dunia material, tetapi tidak materialisme. Islam hanya menempatkan dunia materi sebagai instrumen bukan sebagai asas dan tujuan hidup. Islam menghargai kebebasan mengeluarkan pendapat dan gagasan, tetapi bukan kebebasan mutlak seperti dalam paham liberalisme. Islam menghargai kapital (modal), karena Islam tidak menghendaki gaya hidup konsumtif yang menjurus kepada mubazir, tetapi tidak seperti kapitalisme yang menjurus kepada eksploitasi manusia atas manusia atau semacam "lintah 
darat" yang "mengisap" orang lain (Mahmud, 1998: 75).

Falsafah hidup yang mengglobal dewasa ini seperti di atas (individualisme, sosialisme, liberalisme, dan kapitalisme), bila merasuk ke dalam masyarakat Islam, dinetralisir agar tidak menjadi ekstrem. Untuk menetralisir pahampaham tersebut adalah dengan menghilangkan "isme-isme" yang melekat padanya sehingga tidak diabsolutkan. Dalam posisi seperti itu, umat Islam akan menjadi umat penengah, penetralisir dan menjinakkan pandangan-pandangan tersebut, bukan menjadi umat reaksioner, intoleran, dan eksklusif.

Dengan demikian, Islam tidak harus lari dan mengisolasi diri dari pertarungan ideologi dewasa ini, tetapi Islam justru memberikan warna baru dengan menunjukkan jati dirinya dalam menyikapi persoalan tersebut. Dari titik ini, Islam mampu menciptakan peradaban baru bagi umat Islam pada khususnya dan dunia pada umumnya, dengan memberikan pertimbangan tentang manfaat dan mudharat setiap paham yang ada.

\section{Pemberdayaan Umat dari Segala Lini}

Pada dasarnya Islam adalah agama pemberdayaan. Dalam pandangan Islam, pemberdayaan harus merupakan gerakan tanpa henti. Hal ini sejalan dengan paradigma Islam sendiri sebagai agama gerakan atau perubahan. Dalam konteks Indonesia, masyarakat Islam sebagai penghuni mayoritas bangsa masih terlalu jauh dari segala keunggulan bila dibandingkan dengan sesama umat manusia dari negara-negara lain. Fakta ini menuntut adanya upayaupaya pemberdayaan yang sistematis dan terus menerus untuk melahirkan masyarakat Islam yang berkualitas.

Setidaknya ada tiga kompleks pemberdayaan yang mendesak untuk diperjuangkan dalam konteks keumatan masa kini, yakni:

1. Pemberdayaan pada matra ruhaniah. Degradasi moral atau pergeseran nilai masyarakat Islam saat ini sangat mengguncang kesadaran Islam. Kepribadian kaum muslim terutama mayoritas generasi mudanya begitu telanjang terkontaminasi oleh budaya negatif Barat yang merupakan antitesa dari nilai-nilai Islam. Hal ini juga diperparah dengan gagalnya pendidikan agama di hampir semua lini pendidikan. Untuk keluar dari belitan persoalan ini, masyarakat Islam harus berjuang keras untuk melahirkan desain kurikulum pendidikan untuk setiap wilayah pendidikan, yang benar-benar berorientasi pada pemberdayaan total ruhaniah Islamiah, yang tidak bertentangan dengan perjuangan kebenaran ilmiah dan kemodernan. 
2. Pemberdayaan intelektual. Dengan sangat telanjang, dapat disaksikan betapa umat Islam yang ada di Indonesia bahkan di manapun sudah terlalu jauh tertinggal dalam kemajuan dan penguasaan teknologi. Untuk itu diperlukan upaya berbagai upaya pemberdayaan intelektual sebagai sebuah perjuangan besar (jihad).

Untuk itu, dalam konteks jurisprudensi tanggung jawab sosial Islam, masyarakat Islam harus berani mengedepankan jargon teologi sosial di bawah ini:

a. Bahwa malas belaajr adalah dosa besar sosial Islam

b. Bahwa pemberdayaan intelektual harus merupakan gerakan semua lini keumatan.

c. Bahwa setiap dukungan terhadap gerakan pemberdayaan intelektual harus dipandang sebagai jihad besar yang harus diakselerasikan.

d. Bahwa pada tataran manajemen operasional, masyarakat Islam terutama mereka yang berkecimpung dalam wilayah manajemen korporasi keumatan, harus siap menghadapi gelombang reengineering yang berorientasi pada pada sistem manajemen keunggulan, yang boleh jadi harus meninggalkan pola-pola manajemen dan kepemimpinan yang tidak efektif, efisien, dan produkif untuk diganti dengan pola-pola manajemen kepemimpinan profesional dan strategis. Penolakan terhadap gerakan ini harus dinilai sebagai hambatan-hambatan paling nyata terhadap gerakan pemberdayaan intelektual masyarakat Islam.

e. Bahwa untuk menjalankan ideal ideal di atas, diperlukan gerakan aksional penggalian dan penghimpunan kekuatan-kekuatan ekonomis secara be design, yang diupayakan oleh setiap komponen umat bersama-sama masyarakat Islam, dengan sistem manajemen yang transparan dan professional.

3. Pemberdayaan ekonomi. Umat Islam di Indonesia didentik dengan kemiskinan. Pemecahannya adalah tanggung jawab masyarakat Islam sendiri, yang selama ini selalu terpinggirkan. Situasi ekonomi masyarakat Islam Indonesia bukan untuk diratapi, melainkan untuk dicarikan jalan pemecahannya. Untuk keluar dari himpitan ekonomi ini, diperlukan perjuangan besar dan gigih dari setiap komponen umat. Setiap pribadi Muslim ditantang untuk lebih keras dalam bekerja, berkreasi, dan berwirausaha (entrepreneurship); lebih win-win dalam bekerja, komunikatif 
dalam berinteraksi; lebih skilfull dalam memfasilitasi jaringan kerja, dan lebih professional dalam mengelola potensi-potensi dan kekuatan-kekuatan riil ekonomi umat. Untuk bisa keluar dari himpitan situasi ekonomi seperti sekarang, di samping penguasaan terhadap life skill atau keahlian hidup, keterampilan berwirausaha, dibutuhkan juga pengembangan dan pemberdayaan ekonomi kerakyatan, yang selama ini tidak pernah dilirik (Machendrawaty dkk, 2001: 44-45).

Tentunya, lima poin di atas hanyalah sebagaian kecil gagasan alternatif yang dapat menjadi pemicu lahirnya peradaban baru dalam Islam. Seyogyanya setiap umat Islam harus memikirkan, merenungkan, dan berbuat sesuatu dalam rangka memajukan kembali peradaban Islam dengan memaksimalkan potensi yang ada pada dirinya.

\section{Simpulan}

Kunci utama kejayaan peradaban Islam pada Islam awal adalah keberaniannya untuk menyerbu keluar dan mengambil khasanah keilmuan tanpa mempertanyakan dari mana sumber ilmu pengetahuan tersebut. Semangat keberanian dan kecintaan terhadap ilmu pengetahuan tentu saja lahir dari kemampuan mereka memahami spirit al Quran (ayat pertama yang turun adalah iqra' artinya bacalah). Semangat tersebut seyogyanya dibangkitkan kembali dengan melepaskan diri dari dogma-dogma negatif agama seperti konsep jihad telah tertutup, kehendak mutlak Tuhan, Islam adalah agama orang miskin, kejayaan Islam adalah kejayaan di Akhirat, dan lain sebagainya.

Cita-cita peradaban Islam yang jaya dengan merekonstruksi nalar merupakan hal yang mutlak dilakukan, keyakinan bahwa kejayaan suatu bangsa atau agama yang telah dipergilirkan oleh Allah cukup menjadi dasar keyakinan bahwa umat Islam suatu saat akan bangkit kembali dan merebut kendali peradaban dunia, namun semua itu tidaklah gratis. Sekecil apapun sumbangsi yang anda tawarkan, sangat menentukan cepat lambatnya kejayaan peradaban Islam dapat terwujud.

\section{Daftar Pustaka}

Alisjahbana, Sutan Takdir, dkk., 2001. Sumbangan Islam terhadap Sains dan Peradaban Dunia. Bandung: Yayasan Nuansa Cendekia.

Departemen Agama RI, 2004. Al Quran dan Terjemahnya. Bandung: CV. Penerbit Jumanatul 'Ali ART (J-ART). 
Koentjaraningrat, 2009. Pengantar Ilmu Antropologi. Jakarta: Rineka Cipta.

Mahmud, Moh. Natsir, 1998. Bunga Rampai Epistemologi dan Metode Studi Islam. Ujung Pandang, Institut Agama Islam Negeri Alauddin Press.

Machendrawaty, Nanih dan Safei, Agus Ahmad, 2001. Pengembangan Masyarakat Islam - dari Ideologi, Strategi, sampai Tradisi. Bandung: PT Remaja Rosdakarya.

Nasution, Harun, 1984. Islam Ditinjau dari Berbagai Aspeknya. Jakarta: Universitas Indonesia (UI-Press).

Nasution, Harun, 1973. Falsafah Agama. Jakarta: Bulan Bintang.

Tibi, Basssam, 1999, Islam, Kebudayaan, dan Perubahan Sosial. Terjemahan oleh Misbah Zulfa Elizabet. Yogyakarta: Tiara Wacana Yogya. 